\title{
Effects of Using Narrative Sequential Images on Iranian High School EFL Learners' Monologue Skill
}

\section{Sara Karimzadeh ${ }^{1} \&$ Razieh Rabbani Yekta ${ }^{1 *}$}

\section{* Correspondence: \\ R_ryekta@yahoo.com \\ 1. Department of Linguistics and \\ Foreign Languages, Payame Noor \\ University, Iran}

Received: 22 August 2020

Revision: 23 October 2020

Accepted: 2 January 2021

Published online: 20 March 2021

\begin{abstract}
A narrative monologue skill is required in learning English. Delivering a monologue is a challenging skill for most of the EFL students since it is difficult for them to utilize their lexical and grammatical knowledge. This study investigates the effects of narrative sequential images on the Iranian intermediate EFL students' monologue skill. To this end, the study was conducted in two intact classes (one as the experimental group and the other as the control group) of 32 students within 2 months in a high school in Isfahan. To select homogenous participants, Oxford Placement Test and Oral Proficiency Interview were administered. A monologue pre-test was used at the beginning of the study. And the specific treatment was administered to the experimental group. Then, a parallel post-test was conducted. Based on the results, there was a significant difference in the scores of the experimental group in all aspects of fluency, coherence, lexical resources, grammar and accuracy, and pronunciation in using narrative sequential images before and after treatment. In other words, experimental group performed better on the four subscales of monologue skill than did the control group. Results, also, suggested that teachers use sequential images as a part of their instruction to help students develop their monologue skill.
\end{abstract}

Keywords: images, monologue, narration, picture stories, speaking skill 


\section{Introduction}

According to Graddol (2006), the majority of the people in different countries use English as an international language, thus many countries have agreed to use it as a global language. Speaking is one of the most crucial skills necessary for the effective communication. The ability to communicate effectively has, therefore, become an important need in our lives. According to Kurikulum Tingkat Satuan Pendidikan (KTSP), a narrative monologue is one of the language skills that must be learnt by the students (Misianto, 2017). Today, various teaching methodologies have been used by many teachers in order to select the most effective techniques to help the students improve their monologue skills. Narrative sequential images are an effective learning model which can lead to students' narrative monologue skills improvement. Besides, Purwatiningsih (2015) suggested that using picture series was effective in enhancing the students' participation in the teaching-learning process, the speaking ability of the students, and their interest in learning.

Windihastuti (2013) stated that the students' speaking skill in narrating the texts and the classroom situation of speaking can be improved by using picture series. The speaking skill contained the students' lexical resources, pronunciation, grammar, and fluency, and coherence. Moreover, it has been claimed that this strategy is a proper way to enhance students' interest and motivation in studying English (Misianto, 2017). This study aims to investigate the effects of narrative sequential images on EFL students' monologue skill. To this end, the scores of the pre-test and post-test across different groups with and without image-based instructions are compared.

\subsection{Statement of the Problem}

Speaking is one of the crucial skills in the communication process that often seems to be a cause of problems for many students. Most of the students have problems in speaking especially in delivering monologues in the target language at schools. Since delivering monologues is the most challenging skill, many different methods have been used by many teachers to select the most effective method that helps students enhance their narrative monologue skills (Paulikova, 2019).

Another problem is that there is not any newly developed educational equipment to enhance high school students' interest in delivering monologues in the target language at schools. It is crucial to utilize some tools for increasing the quality of students' speaking and monologue skills. Looking at the challenges above, an innovative and effective strategy should be applied to involve the learners in delivering monologues. Using narrative sequential images is one of the effective techniques that can help EFL students enhance their monologue skills (Misianto, 2017). Moreover, using picture series could enhance the students' speaking skill in telling a story and the situation of the classroom (Windihastuti, 2013).

In order to overcome the above difficulties, using narrative sequential pictures is one of the suggested methods which help students improve their knowledge of lexical resources, pronunciation, grammar and fluency and coherence in monologues (Deacon \& Murphy, 2001). Therefore, the development of narrative monologues in EFL setting for Iranian high school students is the problem investigated in the present study, for which the use of narrative sequential images technique has been suggested as a potential solution.

\subsection{Research Questions}

The current research includes two major questions which were answered in the study, these questions are as follows:

1. Is the use of narrative sequential images effective in the development of EFL learners' narrative monologue skill?

2. Is there any significant difference between monologues of EFL groups with and without narrative sequential images?

\subsection{Research Hypotheses}

To respond the above questions, the following hypotheses are tested:

$\mathrm{H}_{01}$. Using narrative sequential images is not effective in the development of students' narrative monologue skill.

$\mathrm{H}_{02}$. There is no significant difference between monologues of EFL groups with and without narrative sequential images. 


\section{Literature Review}

\subsection{Monologues}

Davis (2007) stated that the monologue is an uninterrupted speech or narrative that a complete line of thought or a complete story is expressed through it. Delivering monologue to a passive audience can be either literally or figuratively, and the audience is onstage at the whole time or part of it. About monologue importance, we can refer to Bruffee (1984 as cited by Davis, 2007) that stated the educator's presentation as a monologue will show the conversational character which is effective and useful in transmitting and comprehending new thoughts.

It can be stated that monologues are useful and helpful in enhancing speaking and eradicating of difficulties. They increase fluency and accuracy in the target language, build and develop confidence, enhance the complexity of speech; and through them, language is acquired by the learners. In details, developing thinking in English, improving fluency and accuracy and complexity of speech, boosting confidence, having good exposure of various and new information in the target language, and forgetting the use of mother tongue are some benefits of monologues (Paulikova, 2019).

\subsection{Sequential Images}

The Oxford English Dictionary defines image as a picture that shows somebody/something. This dictionary also defines sequential as following in order of time or place. Permana (2013) asserted that sequential images are pictures showing sequential and continues happenings of a story. These pictures can be used in order to have a creative language, whether they are in book or flash cards (Harmer, 2001). As stated by Saputra (2016), in teaching learning process, sequential images can be used as the classroom activities by the teachers. These tasks are one means of students' assessment, thus they are used as one of the teaching strategies in which picture is used as a medium.

Misianto (2017) asserted that the use of sequential images as a new learning strategy can enhance the students' skills. The use of this media has new, useful, and fascinating features. Furthermore, interesting and exciting learning environment and achievement of the students' curiosity are two results of using the sequential images media. Based on Purwatiningsih (2015), students' participation in teaching learning process, students' speaking ability, their score and interest in learning a foreign language are enhanced through the use of sequential images. Windihastuti (2013) concluded that the students' speaking skill and the speaking classroom environment could be boosted by means of using the sequential images.

\subsection{Narrative}

The Oxford Dictionary defines narrative as a description of events. According to Omidi and Mahdavi Zafarghandi (2016), short stories, novels, interviews, films, chronicle, and histories are under the scope of narratives. These activities are used to transfer one individual's experience to another by means of oral narratives. According to Labov (1972, 1981), Labov and Waletzky (1967), and Omidi (2016), narrative is defined as personal experience. Johnstone (2001) mentioned that in humanistic and social science, narrative is defined as one of the essential themes; and in linguistics, narrative is known as the most practical thing that people do with talk.

\subsection{Related Studies}

One study that is in line with this research was conducted by Windihastuti (2013) to show the use of picture series on students' enhancement in speaking skill in telling a story and the classroom situation of speaking class. In his research, the students' speaking skill consisted of their lexical resources, pronunciation, grammar, and fluency. The enhancement of classroom situation included a more active class in which students participated in the activities. The result showed that both goals were achieved successfully due to use of picture series that were used by the students.

Another study was done by Nugroho, Sudirman, and Hasan (2015). The goals of this study were to investigate whether there was a difference in students' speaking skill after using three kinds of picture series (taken from comic books, animation movie, Google image), and to know which one is successful for teaching speaking. The participants of the study were 30 students of SMAN. To collect the data, researchers used three times pre-test, three times treatments, three times post-test. The findings revealed that there was a significant increase in students' speaking ability after using picture series which was Google image.

Purwatiningsih (2015) did a research in which the use of sequential images was effective in enhancing students' engagement in teaching learning process and their participation in telling a story. By using this method, he found that $84 \%$ students joined in the teaching learning process. In the case of students' score in his research, he showed that 
$81 \%$ of the students earned scores greater than 75 , and $89 \%$ of the students reacted well toward the use of this media. His research supported his hypothesis that the use of sequential images or picture series has a useful impact on students' learning, interest, and participation in telling stories.

Misianto (2017) carried out a research entitled “Using target-story picture to improve students' narrative monologue skill." His research was a classroom action research which aimed at enhancing a new learning model of narrative monologue by using sequential images. In his study, students worked in groups of four and each group was asked to deliver a monologue by using series of pictures that were given to each group. After several sessions, it was achieved that the students' performance in delivering monologues was improved effectively. Therefore, according to his research, sequential images or target-story picture could be an effective method to deliver monologues.

Research by Novianda (2017) also supported that picture strip stories could help students enhance their speaking skill. In this research, he used an experimental research design with qualitative and quantitative methods. The study had an experimental group which used picture strip stories and a control group which was taught by a typical speaking drill technique. The students' speaking ability was different in both groups as indicated by the t-test. This showed that the students of experimental group, who used picture strip story method, developed more effectively in speaking than those who were in control group without any special treatment.

The last research was conducted by Haq (2019). The study examined the implementation of picture sequence in teaching speaking. There were thirty participants; and observation, questionnaire, and interview were used as ways of data collection. The result of the study represented that picture sequence effectively helped students in learning English speaking skill.

\section{Methodology}

\subsection{Design of the Study}

A quasi-experimental pretest-posttest control group design was used for the study to investigate the effects of sequential images media (independent variable) on the Iranian intermediate EFL students' monologue skill (dependent variable). It's a quasi-experimental study because intact classes were selected due to its availability and convenience.

\subsection{Participants}

Thirty-two Iranian EFL students in two intact classes each consisting of 16 students at Abrar School in Isfahan were selected. They were all girls with the Persian as their native language, with the age range of 15-17, and an average age of 16. The participants were tested for their level of foreign language proficiency in general through Oxford Quick Placement Test and their foreign language oral proficiency through Oral Proficiency Interview. This was done to select homogenous participants.

The participants were divided into two groups, one experimental group and one control group (each group consisting of 16 students). In addition to the student participants, two English teachers scored the interview in Oral Proficiency Test at the beginning of the study, the pre-test, and the post-test according to the International English Language Testing System (IELTS) Assessment Criteria. Both raters were English teachers for more than 5 years and they have master's degree in teaching English language.

Table 1. Demographic background of the participants

\begin{tabular}{ll}
\hline No. of Students & 32 \\
\hline Gender & Female \\
\hline Native Language & Persian \\
\hline Major & EFL \\
\hline Academic Years & $2019-2020$ \\
\hline
\end{tabular}

\subsection{Instruments}




\subsubsection{Oxford Placement Test (OPT)}

To make sure that the participants of the study were at the same level of general English proficiency, Oxford Placement Test was administered to both experimental and control groups prior to the treatment. The test comprises 60 items and the standard time used for the test is 30 minutes. The participants answered all parts of the test related to vocabulary, grammar, and reading comprehension with a maximum possible score of 60 points. According to the test, those participants who earned scores between 28 to 47 were considered as intermediate level. In this test, all 32 participants succeeded in reaching intermediate level.

\subsubsection{Oral Proficiency Interview (OPI)}

To choose homogenous participants for the study with respect to their foreign language oral proficiency, OPI was administered to 32 EFL students. It was used for both the experimental group and the control group. An OPI is a test which measures how well a student's oral skill is. This test takes 5 minutes per student or possibly even less. Participants are expected to be able to answer questions and to interact in conversational English. The test consists of seven parts; Warm up, Identifying objects, Time, Explaining, Describing people, Giving directions, and Warm up again.

In five parts of the test (Identifying objects, Time, Explaining, Describing people, and Giving direction), five pictures were used (taken from www.google.com) to ask questions according to the pictures by pointing at them. The participants' voices were recorded and two different raters scored them. The OPI test is done face to face, with the students and the examiner. In this test, based on raters' holistic interpretation, all participants reached intermediate level. In order to make sure about content validity of the test, it was checked by two raters separately and they had a unanimous agreement on its high content validity.

\subsubsection{Pretest and Posttest}

By using the pre-test and post-test, the researchers wanted to elicit information about the students' monologue skills before and after the treatment. Both pre-test and post-test were selected from www.En.islcollective.com which is a site full of worksheets in all levels and subjects. Several elements were considered to make sure that the tests were parallel. Both of them have the same content which wants students to describe a location. The number of the questions of the tests is the same. Both tests require the same scope of lexical and grammatical knowledge. Besides, the site provides the examiner with the opportunity to choose the appropriate level which is intermediate. Both pre-test and post-test needed the participants to talk about a subject (different but at the same level for each test) for about 3 minutes by considering some points as stated by the researcher. Both tests consist of 5 questions asking about a location, happening and describing the environment.

\subsubsection{Assessment Criteria Chart for Oral Proficiency}

The assessment which was taken from www.SlidePlayer.com was used to evaluate students' oral proficiency. There are four criteria which are necessary for the examiner. Global tasks and functions, Content, Accuracy, and Text type rated from novice to superior. Superior is at the top that shows a wide range of skills in linguistic structures, vocabulary, and fluency. The novice category is the bottom point of the criteria, which represents little functional knowledge of the language. The middle levels are intermediate and advance. 
Table 2. ACTFL oral proficiency interview assessment criteria chart

\begin{tabular}{|c|c|c|c|c|}
\hline $\begin{array}{l}\text { PROFICINC } \\
\text { Y LEVEL }\end{array}$ & $\begin{array}{l}\text { GLOBAL TASKS } \\
\text { AND FUNCTIONS }\end{array}$ & $\begin{array}{c}\text { CONTEXT/CONTE } \\
\text { NT }\end{array}$ & ACCURACY & $\begin{array}{l}\text { TEXT } \\
\text { TYPE }\end{array}$ \\
\hline Superior & $\begin{array}{c}\text { Discuss topics } \\
\text { extensively, support } \\
\text { opinions, and } \\
\text { hypothesize. Deal } \\
\text { with a linguistically } \\
\text { unfamiliar situation. }\end{array}$ & $\begin{array}{l}\text { Most formal and } \\
\text { informal settings. } \\
\text { Wide range of } \\
\text { general interest } \\
\text { topics and some } \\
\text { special fields of } \\
\text { interest and } \\
\text { expertise. }\end{array}$ & $\begin{array}{l}\text { No pattern of errors in } \\
\text { basic structures. Errors } \\
\text { virtually never interfere } \\
\text { with communication or } \\
\text { distract the native } \\
\text { speaker from the } \\
\text { message. }\end{array}$ & $\begin{array}{l}\text { Extended } \\
\text { discourse }\end{array}$ \\
\hline Advanced & $\begin{array}{c}\text { Narrate and } \\
\text { describe in major } \\
\text { time frames and } \\
\text { deal effectively } \\
\text { with an } \\
\text { unanticipated } \\
\text { complication. }\end{array}$ & $\begin{array}{l}\text { Most informal and } \\
\text { some formal settings. } \\
\text { Topics of personal } \\
\text { and general interest. }\end{array}$ & $\begin{array}{l}\text { Understood without } \\
\text { difficulty by speakers } \\
\text { unaccustomed to } \\
\text { dealing with non-native } \\
\text { speakers. }\end{array}$ & $\begin{array}{c}\text { Oral } \\
\text { paragraph/c } \\
\text { onnected } \\
\text { discourse }\end{array}$ \\
\hline Intermediate & $\begin{array}{l}\text { Create with } \\
\text { language, initiate, } \\
\text { maintain, and bring } \\
\text { to a close simple } \\
\text { conversations by } \\
\text { asking and } \\
\text { responding to } \\
\text { simple questions. }\end{array}$ & $\begin{array}{c}\text { Some informal } \\
\text { settings and a limited } \\
\text { number of } \\
\text { transactional } \\
\text { situations. } \\
\text { Predictable, familiar } \\
\text { topics related to daily } \\
\text { activities. }\end{array}$ & $\begin{array}{l}\text { Understood with some } \\
\text { repetition by speakers } \\
\text { accustomed to dealing } \\
\text { with non-native } \\
\text { speakers. }\end{array}$ & $\begin{array}{l}\text { Discrete } \\
\text { sentences }\end{array}$ \\
\hline Novice & $\begin{array}{c}\text { Communicate } \\
\text { minimally with } \\
\text { formulaic and rote } \\
\text { utterances, lists, and } \\
\text { phrases. }\end{array}$ & $\begin{array}{c}\text { Most common } \\
\text { informal settings. } \\
\text { Most common aspects } \\
\text { of daily life. }\end{array}$ & $\begin{array}{l}\text { May be difficult to } \\
\text { understand, even for } \\
\text { speakers accustomed to } \\
\text { dealing with non-native } \\
\text { speakers. }\end{array}$ & $\begin{array}{c}\text { Individual } \\
\text { words and } \\
\text { phrases }\end{array}$ \\
\hline
\end{tabular}

\subsubsection{IELTS Assessment Criteria}

Based on the IELTS Assessment, there are four criteria which are essential for the examiner. Fluency and Coherence, Lexical resources, Grammar range and Accuracy, and Pronunciation that rated from 0 to 9. Both pre-test and post-test were scored and examined according to IELTS Assessment Criteria.

Table 3. IELTS assessment criteria: speaking

\begin{tabular}{lllll}
\hline Band & Fluency and coherence & \multicolumn{1}{c}{ Lexical resource } & $\begin{array}{l}\text { Grammatical range } \\
\text { and accuracy }\end{array}$ & \multicolumn{1}{c}{ Pronunciation } \\
\hline 9 & $\begin{array}{l}\text { • speaks fluently with } \\
\text { only rare repetition or } \\
\text { self-correction; }\end{array}$ & $\begin{array}{l}\text { • uses vocabulary } \\
\text { with full flexibility } \\
\text { and precision in }\end{array}$ & $\begin{array}{l}\text { of uses a full range } \\
\text { of structures } \\
\text { naturally and }\end{array}$ & $\begin{array}{l}\text { ・ uses a full range of } \\
\text { pronunciation } \\
\text { features with }\end{array}$ \\
& any hesitation is & all topics & appropriately & precision and \\
& & & subtlety \\
\hline
\end{tabular}




\begin{tabular}{|c|c|c|c|c|}
\hline & $\begin{array}{l}\text { than to find words or } \\
\text { grammar } \\
\text { - speaks coherently with } \\
\text { fully appropriate } \\
\text { cohesive } \\
\text { features } \\
\text { - develops topics fully } \\
\text { and appropriately }\end{array}$ & $\begin{array}{l}\text { - uses idiomatic } \\
\text { language naturally } \\
\text { and accurately }\end{array}$ & $\begin{array}{l}\text { - produces } \\
\text { consistently } \\
\text { accurate structures } \\
\text { apart } \\
\text { from 'slips' } \\
\text { characteristic of } \\
\text { native speaker } \\
\text { speech }\end{array}$ & $\begin{array}{l}\text { - sustains flexible } \\
\text { use of features } \\
\text { throughout } \\
\text { - is effortless to } \\
\text { understand }\end{array}$ \\
\hline 8 & $\begin{array}{l}\text { - speaks fluently with } \\
\text { only occasional } \\
\text { repetition or } \\
\text { self-correction; } \\
\text { hesitation is usually } \\
\text { content-related } \\
\text { and only rarely to search } \\
\text { for language } \\
\text { - develops topics } \\
\text { coherently and } \\
\text { appropriately }\end{array}$ & $\begin{array}{l}\text { - uses a wide } \\
\text { vocabulary resource } \\
\text { readily and } \\
\text { flexibly to convey } \\
\text { precise meaning } \\
\text { - uses less common } \\
\text { and idiomatic } \\
\text { vocabulary } \\
\text { skillfully, with } \\
\text { occasional } \\
\text { inaccuracies } \\
\text { - uses paraphrase } \\
\text { effectively as } \\
\text { required }\end{array}$ & $\begin{array}{l}\text { - uses a wide range } \\
\text { of structures } \\
\text { flexibly } \\
\text { - produces a } \\
\text { majority of error- } \\
\text { free sentences with } \\
\text { only very } \\
\text { occasional } \\
\text { inappropriacies or } \\
\text { basic/nonsystematic } \\
\text { errors }\end{array}$ & $\begin{array}{l}\text { - uses a wide range } \\
\text { of pronunciation } \\
\text { features } \\
\text { - sustains flexible } \\
\text { use of features, with } \\
\text { only } \\
\text { occasional lapses } \\
\text { - is easy to } \\
\text { understand } \\
\text { throughout; L1 } \\
\text { accent has } \\
\text { minimal effect on } \\
\text { intelligibility }\end{array}$ \\
\hline 7 & $\begin{array}{l}\text { - speaks at length } \\
\text { without noticeable effort } \\
\text { or loss of } \\
\text { coherence } \\
\text { - may demonstrate } \\
\text { language-related } \\
\text { hesitation at } \\
\text { times, or some } \\
\text { repetition and/or self- } \\
\text { correction } \\
\text { - uses a range of } \\
\text { connectives and } \\
\text { discourse } \\
\text { markers with some } \\
\text { flexibility }\end{array}$ & $\begin{array}{l}\text { - uses vocabulary } \\
\text { resource flexibly to } \\
\text { discuss a } \\
\text { variety of topics } \\
\text { - uses some less } \\
\text { common and } \\
\text { idiomatic vocabulary } \\
\text { and shows some } \\
\text { awareness of style } \\
\text { and } \\
\text { collocation, with } \\
\text { some inappropriate } \\
\text { choices } \\
\text { - uses paraphrase } \\
\text { effectively }\end{array}$ & $\begin{array}{l}\text { - uses a range of } \\
\text { complex structures } \\
\text { with some } \\
\text { flexibility } \\
\text { - frequently } \\
\text { produces error-free } \\
\text { sentences, though } \\
\text { some grammatical } \\
\text { mistakes persist }\end{array}$ & $\begin{array}{l}\text { - shows all the } \\
\text { positive features of } \\
\text { Band } 6 \text { and } \\
\text { some, but not all, of } \\
\text { the positive features } \\
\text { of Band } 8\end{array}$ \\
\hline 6 & $\begin{array}{l}\text { - is willing to speak at } \\
\text { length, though may lose } \\
\text { coherence at times due } \\
\text { to occasional repetition, } \\
\text { self-correction or } \\
\text { hesitation }\end{array}$ & $\begin{array}{l}\text { - has a wide enough } \\
\text { vocabulary to discuss } \\
\text { topics at } \\
\text { length and make } \\
\text { meaning clear in spite } \\
\text { of } \\
\text { inappropriacies }\end{array}$ & $\begin{array}{l}\text { - uses a mix of } \\
\text { simple and complex } \\
\text { structures, but } \\
\text { with limited } \\
\text { flexibility }\end{array}$ & $\begin{array}{l}\text { - uses a range of } \\
\text { pronunciation } \\
\text { features with mixed } \\
\text { control } \\
\text { - shows some } \\
\text { effective use of } \\
\text { features but this is }\end{array}$ \\
\hline
\end{tabular}




\begin{tabular}{|c|c|c|c|c|}
\hline & $\begin{array}{l}\text { - uses a range of } \\
\text { connectives and } \\
\text { discourse } \\
\text { markers but not always } \\
\text { appropriately }\end{array}$ & $\begin{array}{l}\text { - generally } \\
\text { paraphrases } \\
\text { successfully }\end{array}$ & $\begin{array}{l}\text { - may make } \\
\text { frequent mistakes } \\
\text { with complex } \\
\text { structures, though } \\
\text { these rarely cause } \\
\text { comprehension } \\
\text { problems }\end{array}$ & $\begin{array}{l}\text { not sustained } \\
\text { - can generally be } \\
\text { understood } \\
\text { throughout, though } \\
\text { mispronunciation of } \\
\text { individual words or } \\
\text { sounds } \\
\text { reduces clarity at } \\
\text { times }\end{array}$ \\
\hline 5 & $\begin{array}{l}\text { - usually maintains flow } \\
\text { of speech but uses } \\
\text { repetition, self- } \\
\text { correction and/or slow } \\
\text { speech to } \\
\text { keep going } \\
\text { - may over-use certain } \\
\text { connectives and } \\
\text { discourse } \\
\text { markers } \\
\text { - produces simple } \\
\text { speech fluently, but } \\
\text { more } \\
\text { complex communication } \\
\text { causes fluency problems }\end{array}$ & $\begin{array}{l}\text { - manages to talk } \\
\text { about familiar and } \\
\text { unfamiliar } \\
\text { topics but uses } \\
\text { vocabulary with } \\
\text { limited flexibility } \\
\text { - attempts to use } \\
\text { paraphrase but with } \\
\text { mixed } \\
\text { success }\end{array}$ & $\begin{array}{l}\text { - produces basic } \\
\text { sentence forms with } \\
\text { reasonable } \\
\text { accuracy } \\
\text { - uses a limited } \\
\text { range of more } \\
\text { complex structures, } \\
\text { but these usually } \\
\text { contain errors and } \\
\text { may cause } \\
\text { some } \\
\text { comprehension } \\
\text { problems }\end{array}$ & $\begin{array}{l}\text { - shows all the } \\
\text { positive features of } \\
\text { Band } 4 \text { and } \\
\text { some, but not all, of } \\
\text { the positive features } \\
\text { of Band } 6\end{array}$ \\
\hline 4 & $\begin{array}{l}\text { - cannot respond } \\
\text { without noticeable } \\
\text { pauses and } \\
\text { may speak slowly, with } \\
\text { frequent repetition and } \\
\text { self-correction } \\
\text { - links basic sentences } \\
\text { but with repetitious use } \\
\text { of } \\
\text { simple connectives and } \\
\text { some breakdowns in } \\
\text { coherence }\end{array}$ & $\begin{array}{l}\text { - is able to talk about } \\
\text { familiar topics but } \\
\text { can only } \\
\text { convey basic } \\
\text { meaning on } \\
\text { unfamiliar topics and } \\
\text { makes frequent errors } \\
\text { in word choice } \\
\text { - rarely attempts } \\
\text { paraphrase }\end{array}$ & $\begin{array}{l}\text { - produces basic } \\
\text { sentence forms and } \\
\text { some correct } \\
\text { simple sentences } \\
\text { but subordinate } \\
\text { structures are } \\
\text { rare } \\
\text { - errors are frequent } \\
\text { and may lead to } \\
\text { misunderstanding }\end{array}$ & $\begin{array}{l}\text { - uses a limited } \\
\text { range of } \\
\text { pronunciation } \\
\text { features } \\
\text { - attempts to control } \\
\text { features but lapses } \\
\text { are } \\
\text { frequent } \\
\text { - mispronunciations } \\
\text { are frequent and } \\
\text { cause some } \\
\text { difficulty for the } \\
\text { listener }\end{array}$ \\
\hline 3 & $\begin{array}{l}\text { - speaks with long } \\
\text { pauses } \\
\text { - has limited ability to } \\
\text { link simple sentences } \\
\text { - gives only simple } \\
\text { responses and is } \\
\text { frequently }\end{array}$ & $\begin{array}{l}\text { - uses simple } \\
\text { vocabulary to convey } \\
\text { personal } \\
\text { information } \\
\text { - has insufficient } \\
\text { vocabulary for less } \\
\text { familiar topics }\end{array}$ & $\begin{array}{l}\text { - attempts basic } \\
\text { sentence forms but } \\
\text { with limited } \\
\text { success, or relies on } \\
\text { apparently } \\
\text { memorized } \\
\text { utterances }\end{array}$ & $\begin{array}{l}\text { - shows some of the } \\
\text { features of Band } 2 \\
\text { and some, } \\
\text { but not all, of the } \\
\text { positive features of } \\
\text { Band } 4\end{array}$ \\
\hline
\end{tabular}




\begin{tabular}{|c|c|c|c|c|}
\hline & $\begin{array}{l}\text { unable to convey basic } \\
\text { message }\end{array}$ & & $\begin{array}{l}\text { - makes numerous } \\
\text { errors except in } \\
\text { memorized } \\
\text { expressions }\end{array}$ & \\
\hline 2 & $\begin{array}{l}\text { - pauses lengthily before } \\
\text { most words } \\
\text { - little communication } \\
\text { possible }\end{array}$ & $\begin{array}{l}\text { - only produces } \\
\text { isolated words or } \\
\text { memorized } \\
\text { Utterances }\end{array}$ & $\begin{array}{l}\text { - cannot } \\
\text { basic } \\
\text { forms }\end{array}$ & $\begin{array}{l}\text { - speech is often } \\
\text { unintelligible }\end{array}$ \\
\hline 1 & \multicolumn{4}{|c|}{$\begin{array}{l}\text { - no communication possible } \\
\text { - no rateable language }\end{array}$} \\
\hline 0 & - does not attend & & & \\
\hline
\end{tabular}

\subsubsection{Sequential Images}

Thirty-two series of pictures at intermediate level were used for the experimental group. Most of the series were taken from www.pinterest.com which is a site with pictures in different levels. All of the 32 series were selected in a way that was appropriate to be used in the class. These series of pictures were selected considering students' intermediate level, their acquaintance with the stories, and their lexical and grammatical knowledge. According to the criterion set by Brown (2003), the numbers of pictures in each series were three to six. Moreover, the same textbook (Vision 2) was taught to the groups. Their textbook didn't include any narrative tasks.

\subsection{Data Collection Procedure}

\subsubsection{Pilot Study}

Prior to the treatment, the researchers carried out a pilot study to make sure that the subsequent formal study ran smoothly. The goal of the pilot study was to find out instrument validity and procedural reliability. It is also conducted to ensure about the inter-rater reliability since both pre-test and post-test were recorded and two raters scored them. The pilot study was also conducted to ensure the reliability of the OPI test. To reach the above goals, a group of 4 students were selected to test all the procedures and steps including Oxford Placement Test, Oral Proficiency Interview, pretest, and posttest and sequential images.

\subsubsection{Main Study}

The following steps were followed in the process of carrying out the study.

At the first stage, an OPT was given to the participants to ensure their suitable placement at the intermediate level and then an OPI was given to the participants to make sure that they were at the same foreign language proficiency in speaking ability prior to the treatment. Hence, 32 participants were selected. Then pre-test was conducted on those 32 participants. The experiment was carried out during regular class periods. The course was made up of 8 weekly sessions in two months with each session lasting about 90-minutes. In order to address the first two research questions, the participants were divided into two groups: one experimental group that consisted of 16 participants and one control group that was made up of 16 participants, too.

At the first session, the procedures of the study were explained by the researcher. She taught the participants in the experimental group how to do the required tasks in the class by dividing them into groups of four. The participants needed to know all about the visual narrative sequential images, and the teacher acted as a facilitator. In the experimental group, after dividing the students into four groups of 4, each group was given an envelope comprising a series of pictures of different stories; then the teacher wanted the students to discuss and talk about the pictures and put them in order collaboratively in their groups.

The teacher assigned each group to deliver a narrative monologue in turns based on the sequential pictures. Each session, four students (one from each group) put the pictures in the suitable order into some slots which were already fixed on the whiteboard and delivered the monologue. The available time for each group was 6 minutes to prepare and 
4 minutes to present their monologue. It is worth mentioning that picture stories were developed in two groups of 16 series; in the first group, each series consisted of 3 to 4 pictures; and in the second one, each consisted of 5 to 6 pictures. In the first 4 weeks, the stories that were made up of 3 to 4 pictures were given to the groups. And in the second 4 weeks, the stories that were made up of 5 to 6 pictures were given to the groups. Thus, during the treatment sessions, each student delivered two monologues after collaborating in her group.

Only the experimental group received this treatment during sessions, but the control group did not receive this treatment. It is worth mentioning that the same teacher taught the same textbook (Vision 2) to both of the groups. Their textbook didn't include any narrative tasks. The only difference was specific treatment which was done to the experimental group for a specific time in each session. After 8 sessions, the post-test was conducted. The scores on the post-test ranged from 0-9 based on IELTS Assessment Rubric. The data were collected from the performance of the control and the experimental groups, and then the data were analyzed.

\subsection{Data Analysis Procedure}

To analyze the data, one Independent Sample T-Test and two Paired Sample T-Tests were used to check the difference between the experimental and the control group.

\section{Results}

\subsection{The Effects of Using Narrative Sequential Images}

To answer the first research question which asks: "Is the use of narrative sequential images effective in the development of EFL learners' narrative monologue skill?", at first a Paired Sample T-Test was run to check the possible differences between the results of the pre-test and the post-test in the control group. The following results were achieved.

Table 4. Paired samples T-test of control group's pre- and post- test data

\begin{tabular}{|c|c|c|c|c|c|c|}
\hline \multicolumn{7}{|c|}{ Mean \pm Std. Deviation } \\
\hline \multirow[t]{2}{*}{ Variables } & \multirow[t]{2}{*}{$\mathrm{N}$} & & & \multirow[t]{2}{*}{$\mathrm{t}$} & \multirow[t]{2}{*}{$\mathrm{Df}$} & \multirow{2}{*}{$\begin{array}{l}\text { Sig. (2- } \\
\text { tailed) }\end{array}$} \\
\hline & & Pretest & Posttest & & & \\
\hline Fluency and Coherence & 16 & $5.69 \pm .704$ & $5.69 \pm .704$ & 0 & 15 & 1 \\
\hline Lexical Resources & 16 & $4.25 \pm .931$ & $4.38 \pm .957$ & -1.464 & 15 & .164 \\
\hline Grammar and Accuracy & 16 & $6.50 \pm .816$ & $6.38 \pm .719$ & 1.464 & 15 & .164 \\
\hline Pronunciation & 16 & $6.63 \pm .500$ & $6.69 \pm .479$ & -1.000 & 15 & .333 \\
\hline
\end{tabular}

There wasn't a significant difference in the scores for all aspects of fluency and coherence, lexical resources, grammar and accuracy and pronunciation in pre-test $(\mathrm{M}=5.69, \mathrm{SD}=.704 ; \mathrm{M}=4.25, \mathrm{SD}=.931 ; \mathrm{M}=6.50, \mathrm{SD}=.816 ; \mathrm{M}=6.63, \mathrm{SD}=$ $.500)$ and in post-test $(\mathrm{M}=5.69, \mathrm{SD}=.704 ; \mathrm{M}=4.38, \mathrm{SD}=.957 ; \mathrm{M}=6.38, \mathrm{SD}=.719 ; \mathrm{M}=6.69, \mathrm{SD}=.479)$ conditions; $\mathrm{t}(15)=0, \mathrm{p}=1 ; \mathrm{t}(15)=-1.464, \mathrm{p}=.164 ; \mathrm{t}(15)=1.464, \mathrm{p}=.164 ; \mathrm{t}(15)=-1.000, \mathrm{p}=.333$. The same method of statistical analysis (i.e., a paired sample T-test) was also run between the pre-test and post-test scores in the experimental group. The results have been indicated in the following table. 
Table 5. Paired samples T-test of experimental group's pre- and post- treatment data

\begin{tabular}{ccccccc}
\hline \multirow{2}{*}{ Variables } & $\mathrm{N}$ & & & & \\
& & & & Mean \pm Std. Deviation & Df & $\begin{array}{c}\text { Sig. (2- } \\
\text { tailed) }\end{array}$ \\
\cline { 3 - 6 } & & Before treatment & After treatment & & & \\
\hline Fluency and Coherence & 16 & $5.81 \pm .655$ & $7.44 \pm .629$ & -13.00 & 15 & .000 \\
\hline Lexical Resources & 16 & $4.25 \pm 1.000$ & $6.06 \pm .998$ & -9.667 & 15 & .000 \\
\hline Grammar and Accuracy & 16 & $6.25 \pm .775$ & $7.38 \pm .719$ & -6.260 & 15 & .000 \\
\hline Pronunciation & 16 & $6.75 \pm .683$ & $7.56 \pm .629$ & -4.333 & 15 & .001 \\
\hline
\end{tabular}

There was a significant difference in the scores for all aspects of fluency and coherence, lexical resources, grammar and accuracy and pronunciation before treatment $(\mathrm{M}=5.81, \mathrm{SD}=.655 ; \mathrm{M}=4.25, \mathrm{SD}=1.000 ; \mathrm{M}=6.25, \mathrm{SD}=.775 ; \mathrm{M}=$ $6.75, \mathrm{SD}=.683)$ and after treatment $(\mathrm{M}=7.44, \mathrm{SD}=.629 ; \mathrm{M}=6.06, \mathrm{SD}=.998 ; \mathrm{M}=7.38, \mathrm{SD}=.719 ; \mathrm{M}=7.56, \mathrm{SD}=$ .629 ) conditions; $\mathrm{t}(15)=-13.00, \mathrm{p}=.000 ; \mathrm{t}(15)=-9.667, \mathrm{p}=.000 ; \mathrm{t}(15)=-6.260, \mathrm{p}=.000 ; \mathrm{t}(15)=-4.333, \mathrm{p}=.001$.

\subsection{Differences between Monologues of the Groups}

To answer the second research question which asks: "Is there any significant difference between monologues of EFL groups with and without narrative sequential images?", an Independent Samples T-Test was conducted to compare the two groups' narrative monologue skills when one of them (the experimental group) was exposed to the picture story tasks with sequential images and one of them (the control group) was not.

Table 6. Group statistics for the monologue post-test

\begin{tabular}{lllccc}
\hline & \multicolumn{3}{c}{ Group Statistics } & & \\
\hline & VAR00001 & $\mathrm{N}$ & Mean & $\begin{array}{c}\text { Std. } \\
\text { Deviation }\end{array}$ & $\begin{array}{c}\text { Std. Error } \\
\text { Mean }\end{array}$ \\
\hline Fluency and Coherence & Control & 16 & 5.69 & .704 & .176 \\
\cline { 2 - 6 } & Experiment & 16 & 7.44 & .629 & .157 \\
\hline Lexical Resources & Control & 16 & 4.38 & .957 & .239 \\
\cline { 2 - 6 } & Experiment & 16 & 6.06 & .998 & .249 \\
\hline Grammar and Accuracy & Control & 16 & 6.38 & .719 & .180 \\
\cline { 2 - 6 } & Experiment & 16 & 7.38 & .719 & .180 \\
\hline Pronunciation & Control & 16 & 6.69 & .479 & .120 \\
\cline { 2 - 5 } & Experiment & 16 & 7.56 & .629 & .157 \\
\hline
\end{tabular}


Table 7. Independent samples T-test for the monologue test

Independent Samples Test

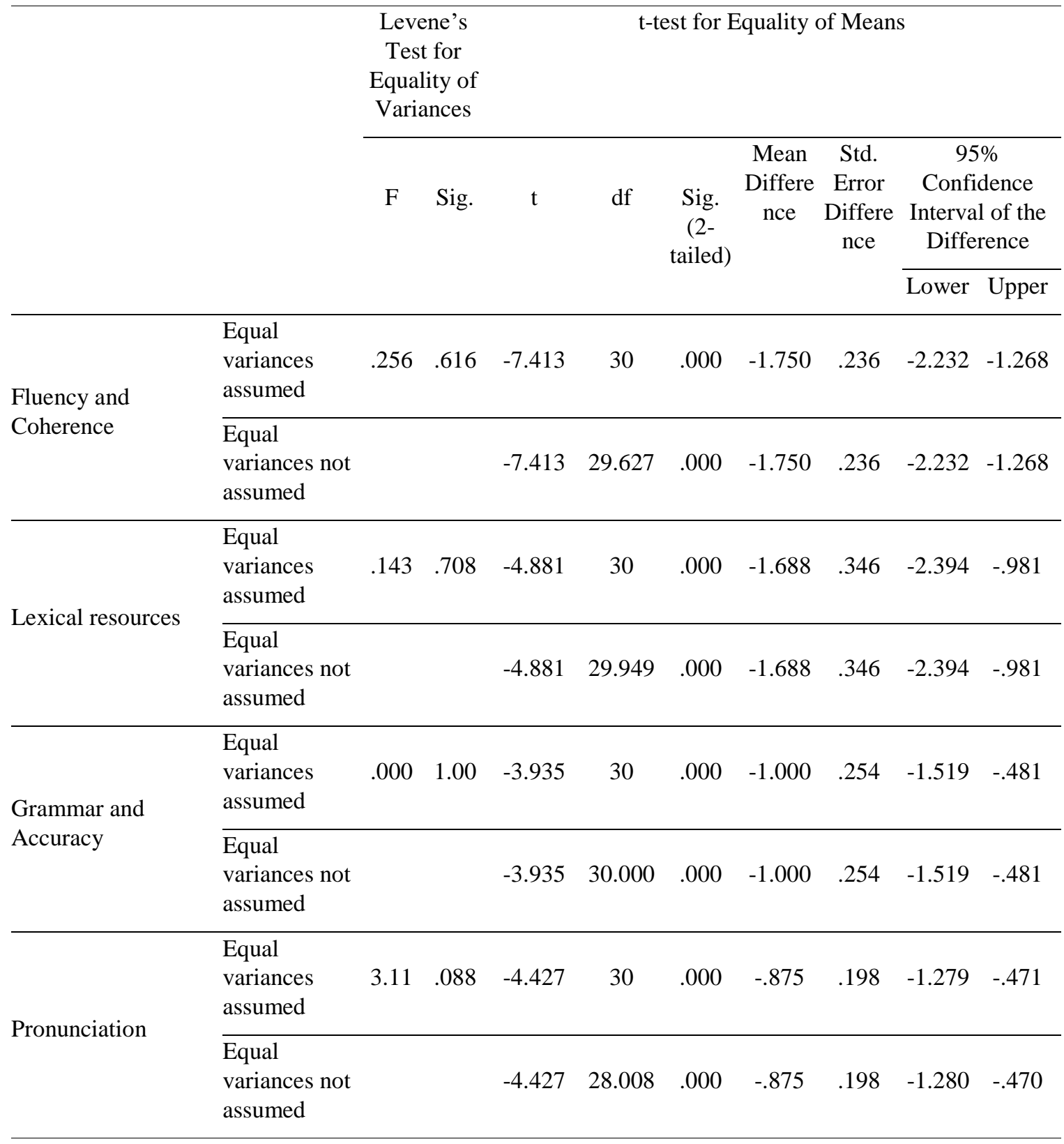

Through examining the control and experimental groups by carrying out Independent Samples T-Test, the following results were inferred:

Because the Sig. value was less than alpha of .001 , it was noticed that there was a significant difference in the scores between the control group ( $\mathrm{M}=5.69, \mathrm{SD}=.704 ; \mathrm{M}=4.38, \mathrm{SD}=.957 ; \mathrm{M}=6.38, \mathrm{SD}=.719 ; \mathrm{M}=6.69, \mathrm{SD}=.479)$ and the experimental group $(\mathrm{M}=7.44, \mathrm{SD}=.629 ; \mathrm{M}=6.06, \mathrm{SD}=.998, \mathrm{M}=7.38, \mathrm{SD}=.719 ; \mathrm{M}=7.56, \mathrm{SD}=.629)$ in all four categories; fluency and coherence, lexical resources, grammar and accuracy and pronunciation $(\operatorname{sig}=.000)$. 


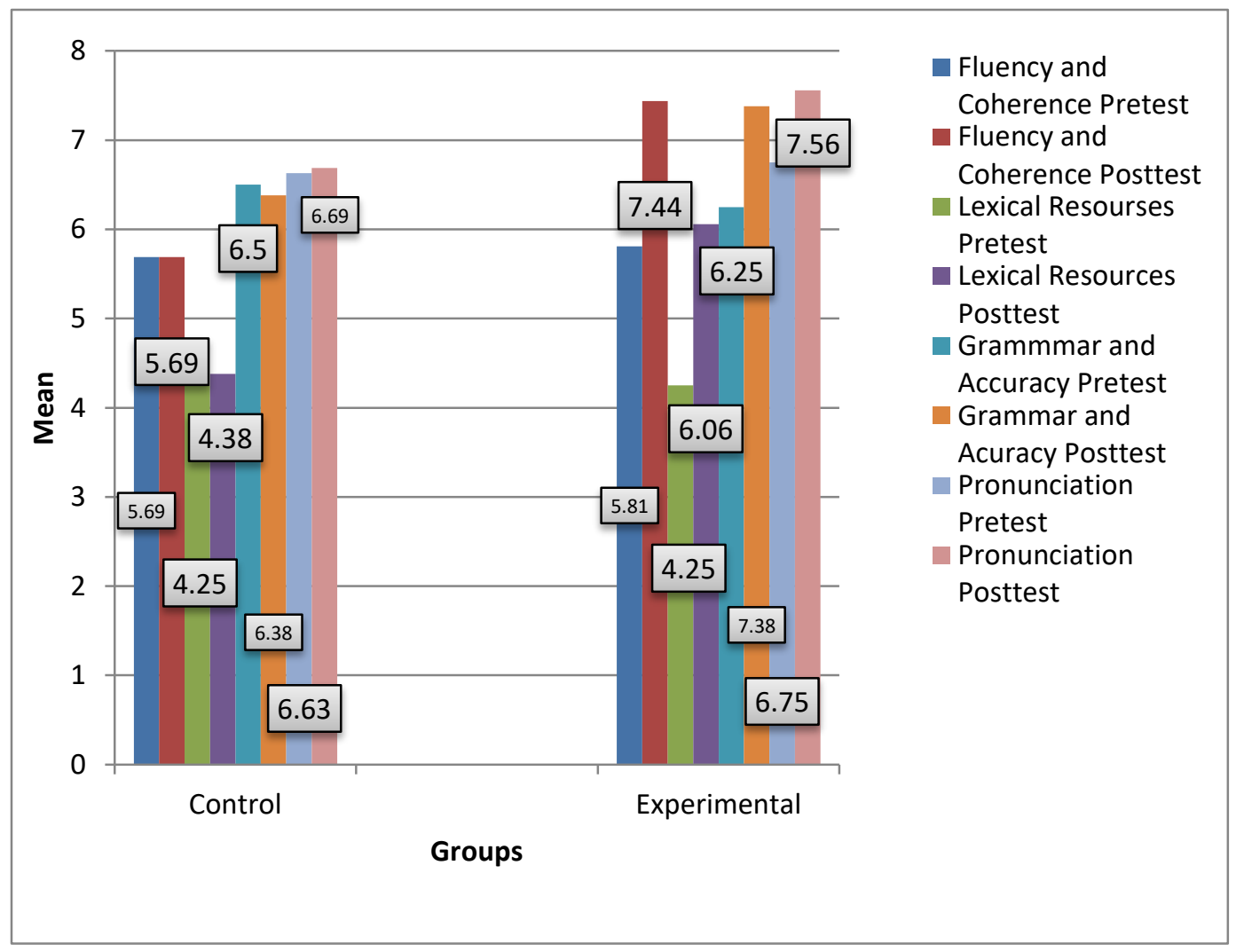

Figure 1. The Comparison between the means of the two groups on four levels of the monologue test.

Based on the results and explanations, there was a significant difference in the scores of all aspects of fluency and coherence, lexical resources, grammar and accuracy, and pronunciation in using narrative sequential images before and after treatment. And it was inferred that because the mean of the scores in all aspects in experimental group was much greater than the mean of the scores in control group, experimental group performed better on the four categories than did the control group. In short, the null hypothesis was rejected and it was proved that the narrative monologue learning model using sequential images succeeded in improving the students' ability of narrative monologue.

\section{Discussion}

This study aimed to investigate the effects of using narrative sequential images on Iranian intermediate EFL students' monologue. As the answer to the first research question, in the monologue test that was administered at the pre-test and post-test, it was noticed that the experimental group performed better on the pronunciation aspect of the test than did the control group. The same result was also reported as to the improvement of the fluency and coherence, lexical resources, grammar and accuracy. The results support some of the results found in the literature, which indicate that students' speaking skill can be enhanced by sequential images (Nisa, 2013; Novianda, 2017; Nugroho, Sudirman \& Hasan, 2015; Windihastuti, 2013; Zainatudar, 2015).

The results are also consistent with general findings of Haq's research (2019) which indicates that by the use of picture sequences, students act much better in their productions and improve in learning English speaking skill .This study proves the Aska, Hasan, and Supriyadi's (2014) findings as well. They reported that using picture series is helpful in teaching speaking skills. In their study, students' speaking skill was developed in three aspects of pronunciation, vocabulary, and grammar. Also, students' motivation was enhanced during teaching learning processes, and students became more energetic and active in classroom activities.

As to the effects on lexical resources, Hidayat (2017) and Kirsch (2012) are two scholars who reported the similar results; that is, the positive effects of storytelling on the vocabulary development. Regarding the change in the 
coherence of the students' productions, results are in accordance with Ramadhani, Raja, and Putrawan (2017) who reported that the picture sequence tasks could affect the organization and coherence of the students' language productions in a positive way.

As to the second research question, there were significant differences between the experimental group and control group in the use of sequential images, while both groups had been equal in terms of the teacher and the main student book and the teaching methodology except the use of sequential images which was specific for the experimental group. Therefore, based on the results, sequential images significantly affected the Iranian intermediate EFL students' monologue skill.

These results are in line with Misianto (2017) who stated that students' performance in delivering monologues was improved effectively through using narrative sequential images. He continued that sequential images or target-story pictures can be an effective method to deliver monologues. The results of this research are consistent with the findings of Purwatiningsih (2015) who believed that using sequential images was effective in enhancing students' engagement in teaching learning process and their participation. He stated that the use of sequential images or picture series has a beneficial impact on students' learning, interest, enthusiasm, and participation in the classroom.

\section{Conclusion}

The aim of this study was to investigate the effects of sequential images on Iranian intermediate EFL learners' monologue skill. The results proved that using sequential images does improve EFL learners' monologue. The findings represent that using the sequential images technique enhances the Iranian intermediate EFL students' monologue in terms of lexical resources, fluency and coherence, grammar and accuracy, and pronunciation. The findings shed light on what and how to teach delivering monologue in EFL classes. This research is beneficial for both the learners and the teachers. According to the outcomes of this study, it is suggested that teachers use sequential images as a part of their instruction to help students develop their monologue skill. It also proved that the narrative monologue learning model using sequential images toward which students have positive attitudes succeeded in improving the students' ability of narrative monologue and creating a fun monologue learning atmosphere in the class.

\section{References}

Aska, R. F., Hasan, B., \& Supriyadi, D. (2014). The use of picture series to increase students' speaking ability (Unpublished master's thesis). University of Lampung.

Brown, H. D. (2003). Language assessment: Principles and classroom practices. Pearson ESL.

Bruffee, K. (1984). Collaborative learning and the conversation of mankind. College English, 46(7), 635-652. http://doi.org/10.2307/376924

Davis, J. (2007). Dialogue, monologue and soliloquy in the large lecture class. International Journal of Teaching and Learning in Higher Education, 19(2), 178-182. http://www.semanticscholar.org/paper/Dialogue\%2CMonologue-and-Soliloquy-in-the-Large-Davis/44b9222e9f7050d8f10eaa2bb18fa197a3f4634a

Deacon, B., \& Murphey, T. (2001). Deep impact storytelling. English Teaching Forum, 39(4), 26-41. http://eric.ed.gov/?id=EJ652211

Graddol, D. (2006). English next. The British Council \& the English Company (UK) Ltd.

Haq, R. H. F. (2019). The use of picture sequence in teaching speaking (A study at training class- TC- students of basic English course- BEC - pare) [Unpublished master's thesis]. Walisongo State Islamic University Semarang.

Harmer, J. (2001). The practice of English language teaching (3rd ed.). Pearson Education ESL.

Hidayat, K. (2017). The effect of using flash card and picture story in vocabulary mastery to the seventh grader of Smp Pgri 1 Margatiga. Premise Journal, 5(2), 10. doi: http://dx.doi.org/10.24127/pj.v5i2.812

Johnstone, B. (2001). Discourse analysis and narrative. In D. Schiffrin, D. Tannen, \& H. E. Hamilton (Eds.), the handbook of discourse analysis (1st ed., pp. 635-649). Blackwell Publishers.

Kirsch, C. (2012). Using storytelling to teach vocabulary in language lessons: does it work? The Language Learning Journal, 44(1), 33-51. doi: 10.1080/09571736.2012.733404 
Labov, W. (1972). The transformation of experience in narrative syntax. In Language in the inner city (pp. 354-405). University of Pennsylvania Press.

Labov, W. (1981). Speech actions and reactions in personal narrative. In D. Tannen (Ed.), Analyzing discourse: Text and talk (pp. 219-247). Georgetown University Press.

Labov, W., \& Waletzky, J. (1967). Narrative analysis: Oral version of personal experience. In J. Helm (Ed.), Essays on the verbal and visual arts: Proceedings of the 1966 annual spring meeting of the American ethnological society (pp. 12-44). University of Washington Press.

Misianto, M. (2017). Using target-story picture to improve students' narrative monologue skills. EnJourMe (English Journal of Merdeka): Culture, Language, and Teaching of English, 2(2), 98-104. https://doi.org/10.26905/enjourme.v2i2.1664

Nisa, D. K. (2013). The effectiveness of using picture cued task to improve students speaking skill in narrative text of the eleventh grade students of SMA Negeri 1 Comal in the academic year 2013/2014 (Unpublished master's thesis). Semarang State University.

Novianda, R. (2017). Teaching speaking by using picture strip stories. English Education Journal (EEJ), 8(3), 386403. http://jurnal.unsyiah.ac.id/EEJ/article/view/8925

Nugroho, L., Sudirman, S., \& Hasan, H. (2015). The use of picture series in improving students' speaking recount text skill. UNILA Journal of English Teaching, 4(1). http://www.neliti.com/publications/193534/the-use-ofpicture-series-in-improving-students-speaking-recount-text-skill\#cite

Omidi, M., \& Mahdavi Zafarghandi, A. (2016). The effect of short-story retelling on the Iranian intermediate EFL students' speaking skills. Journal of Applied Linguistics and Language Research, 3(4), 234-252. http://www.jallr.com/index.php/JALLR/article/view/347/pdf347

Pauliková, K. (2019). Use of monologues, games and problem solving activities for development of speaking skills. Educational Role of Language Journal, 1(1), 83-92. https://doi.org/10.36534/erlj.2019.01.08

Permana, T. D. (2013). The implementation of picture series as media in teaching writing of a narrative text of the tenth graders of senior high school. Research on English Language Teaching in Indonesia, 1(1), 1-8. https://dokumen.tips/documents/the-implementation-of-picture-series-as-media-in-teaching-writing-of-anarrative.html

Purwatiningsih, P. (2015). Improving speaking ability through story telling technique by using picture series. Journal on English as a Foreign Language, 5(1), 57-66. https://doi.org/10.23971/jefl.v5i1.93

Ramadhani, A., Raja, P., \& Putrawan, G. E. (2017). The implementation of picture sequence technique in teaching procedure text writing at the third year of SMPN 23 Bandar Lampung. U-JET, 6(5).

Saputra, N. A. (2016). The implementation of picture-cued tasks in writing class: An action research at SMA Muhammiyah 4 Yogyakarta [Unpublished master's thesis]. Universitas Muhammiyah Yogyakarta. http://repository.umy.ac.id/handle/123456789/7170

Windihastuti, R. (2013). Improving students' speaking skill by using picture series (Unpublished master's thesis). Sebelas Maret University.

Zainatudar, Z. (2015). Teaching speaking in English by using the picture series technique. English Education Journal, 6(4), 450-451. http://www.jurnal.unsyiah.ac.id/EEJ/article/view/2854 